\author{
Małgorzata MICHALEWSKA-PAWLAK (D) \\ Uniwersytet Wrocławski \\ malgorzata.michalewska-pawlak@uwr.edu.pl
}

\author{
Monika KLIMOWICZ iD \\ Uniwersytet Wrocławski \\ monika.klimowicz@uwr.edu.pl
}

\title{
WZROST ZNACZENIA INSTRUMENTÓW INWESTYCYJNYCH W POLITYCE REGIONALNEJ UNII EUROPEJSKIEJ W PERSPEKTYWIE FINANSOWEJ 2014-2020
}

ABSTRACT The Increase of Significance Investment Instruments in Regional Policy of the European Union after 2014

The main objective of this paper is to analyse the increase of significance investment instruments in regional policy of the European Union after 2014. The reasons of this phenomenon have been pointed out in the context of the European Union structural funds. They refer to political interests, economic, social environmental challenges faced by the EU regions under conditions of limitation the EU expenditure on regional development financing. Solutions in the following areas: objectives, priorities and rules of intervention of the structural funds have been presented - those which have an investment dimension. Investment approach is going to be carried on in the next Multiannual Financial Framework after 2020. The paper has been elaborated based on using method of institutional analysis the key EU regional policy legal regulations and existing scientific literature.

Keywords: European Union, regional policy, structural funds, investments, Europe 2020 strategy

Słowa kluczowe: Unia Europejska, polityka regionalna, fundusze strukturalne, inwestycje, strategia Europa 2020 


\section{WSTĘP}

Głównym celem artykułu jest ukazanie wzrostu znaczenia instrumentów inwestycyjnych, który zauważyć można w polityce regionalnej Unii Europejskiej (UE) po 2014 r. Przedstawione zostały zarówno przyczyny tego zjawiska, jak i zmiany, jakie zaszły w programowaniu i wdrażaniu działań, świadczące o poszerzeniu paradygmatu inwestycyjnego w kontekście obszarów interwencji dwóch instrumentów finansowych polityki regionalnej UE, a mianowicie: Europejskiego Funduszu Rozwoju Regionalnego (EFRR) oraz Europejskiego Funduszu Społecznego (EFS). Wymienione fundusze strukturalne wraz z Funduszem Spójności, Europejskim Funduszem Rolnym na rzecz Rozwoju Obszarów Wiejskich oraz Europejskim Funduszem Morskim i Rybackim stanowią instrumenty ukierunkowane na podnoszenie spójności oraz poziomu rozwoju regionów i państw UE. Dla pełnego zrozumienia przedstawionej w niniejszym artykule analizy warto zaznaczyć, iż inwestycyjny charakter instrumentów polityki regionalnej rozumiany jest jako ich orientacja na generowanie trwałych i mierzalnych korzyści ekonomicznych, społecznych i środowiskowych. W kontekście unijnych celów rozwojowych za inwestycyjne uznawane są te instrumenty interwencji, które mają się przyczynić do realizacji celów UE zdefiniowanych w strategii Europa 2020 związanych z promowaniem rozwoju inteligentnego, zrównoważonego i sprzyjającego włączeniu społecznemu. Jednocześnie wraz ze wzrostem roli inwestycji wspomagających tak rozumiany rozwój odnotowuje się spadek znaczenia redystrybucyjnego i kompensacyjnego wymiaru polityki regionalnej, zorientowanego na zwiększenie spójności międzyregionalnej w UE.

W pierwszej części tekstu zawarto charakterystykę wyzwań ekonomicznych, społecznych i środowiskowych stojących przed regionami UE, w warunkach ograniczania wydatków unijnego budżetu na finansowanie rozwoju regionalnego. Wskazano, że problemy rozwojowe zdiagnozowane jako wspólne dla całej UE i jej poszczególnych regionów oraz redukcja wydatków na politykę regionalną, związana z kryzysem finansowym z 2009 r., mają wpływ na zarządzanie EFRR i EFS. Przedstawiony został także polityczny kontekst wzmocnienia inwestycyjnego wymiaru funduszy strukturalnych. Determinantem stał się w tym przypadku model rozwoju społeczno-gospodarczego scharakteryzowany w strategii Europa 2020, który miał zostać zrealizowany za pomocą odpowiednio ukierunkowanych inwestycji, zarówno w kontekście wzrostu konkurencyjności unijnej gospodarki jako całości, jak i gospodarek narodowych państw członkowskich UE.

Konsekwencją przyjętego założenia metodologicznego jest zaprezentowana w kolejnej części artykułu analiza dotycząca doboru celów, priorytetów i zasad interwencji funduszy strukturalnych w latach 2014-2020, której wyniki wskazują na ich inwestycyjny charakter. Wykazane zostało, iż wymienione fundusze inwestowane są w te dziedziny tematyczne, które przyczyniają się do wzrostu konkurencyjności regionalnych gospodarek oraz maksymalizują wykorzystanie potencjału gospodarczego i ludzkiego poszczególnych regionów. Dowodem na to jest między innymi coraz większe znaczenie 
takich elementów jak: koncentracja tematyczna, inteligentne specjalizacje i instrumenty finansowe zwrotne wdrażane w ramach EFRR czy inwestycje społeczne będące jednym z głównych priorytetów interwencji EFS. Podejście inwestycyjne wzmocnione zostało równocześnie poprzez system planowania strategicznego oraz takie rozwiązania finansowe jak rezerwy na wykonanie lub warunkowość ex-ante, traktowana jako swoistego rodzaju narzędzie motywujące dla podmiotów wykazujących się efektywnością w osiąganiu priorytetów polityki regionalnej.

W artykule celowo posłużono się pojęciem polityki regionalnej rozumianej jako interwencja publiczna, której celem jest wspieranie przekształceń strukturalnych w regionach, w wymiarze ekonomicznymi i społecznym. W związku z tym, iż obecnie realizowana polityka regionalna UE stanowi zasadniczą część polityki spójności, w artykule pominięto instrumenty, które wspierają rozwój regionów, ale dedykowane są, w zakresie horyzontalnym i sektorowym, wsparciu państw członkowskich w osiąganiu ich celów rozwojowych.

Zastosowane $\mathrm{w}$ procesie opracowania artykułu metody badawcze objęły analizę instytucjonalną aktów prawnych i innych dokumentów unijnych w obszarze polityki regionalnej UE, wykorzystano również ustalenia zawarte w najnowszej naukowej literaturze przedmiotu, dane statystyczne dotyczące gospodarczej i społecznej sytuacji regionów UE wygenerowane przez Eurostat, a także informacje pochodzące z oficjalnych portali internetowych Komisji Europejskiej (KE). Podstawę do sformułowania wniosków dotyczących polityki regionalnej UE po 2020 r. stanowiła także obserwacja bieżącej sytuacji ekonomicznej i politycznej UE.

\section{PRZYCZYNY WZROSTU ZNACZENIA INWESTYCYJNEGO WYMIARU POLITYKI REGIONALNEJ UNII EUROPEJSKIEJ}

Polityka regionalna realizowana na poziomie wspólnotowym od wejścia w życie 1 lipca 1987 r. Jednolitego aktu europejskiego, ustanawiającego zapisy o spójności społecznej i gospodarczej ${ }^{1}$, miała na celu wsparcie regionów opóźnionych w rozwoju, dotkniętych problemami z powodu zmian struktury gospodarczej oraz tych obszarów, które ze względu na swoje położenie czy warunki przyrodnicze doświadczały różnego typu ograniczeń rozwojowych. Wykazywała ona silną orientację na osiąganie międzyregionalnej spójności w wymiarze ekonomicznym, społecznym, a od 2009 r. także i terytorialnym. Praktyka implementacji modelu polityki regionalnej UE zorientowanego na niwelowanie dysproporcji rozwojowych i zapewnienie równych szans w rozwoju regionów, opartego na redystrybucji środków finansowych, pokazała, iż ma ona uzasadnienie ze względów społecznych. Natomiast nie jest w stanie zlikwidować znaczących różnic związanych z odmiennymi potencjałami rozwojowymi regionów i sposobami ich wykorzystania czy nierówną alokacją zasobów w wymiarze

I. Pietrzyk, Polityka regionalna Unii Europejskiej i regiony w państwach cztonkowskich, Warszawa 2000, s. 92. 
międzyregionalnym² ${ }^{2}$. Co więcej, wielu badaczy stwierdza, że efekty gospodarcze osiągane za pomocą transferów funduszy strukturalnych są zróżnicowane, ze względu na charakter regionu i poziom jego rozwoju, a także szereg czynników o charakterze endogenicznym ${ }^{3}$.

Nie tylko dane potwierdzające ograniczony wpływ funduszy strukturalnych na rozwój uboższych regionów UE powodują rewizję i reorientację celów, priorytetów i instrumentów polityki regionalnej. Jak zauważają badacze, mimo uwspólnotowienia polityki regionalnej UE i przekazania kompetencji strategicznych oraz regulacyjnych Parlamentowi Europejskiemu i Radzie, a operacyjnych KE, wpływ państw członkowskich na wypracowywanie celów, ram organizacyjnych i finansowych tej polityki oraz jej faktyczną implementację jest nadal znaczący ${ }^{4}$.

Oddziaływanie na rozwój inwestycyjnego wymiaru polityki regionalnej miały bez wątpienia państwa członkowskie, które domagały się redefinicji jej założeń w związku z przystąpieniem do UE słabiej rozwiniętych państw Europy Południowej i Środkowo-Wschodniej w 2004 i 2007 r. Przy zastosowaniu kryterium podziału funduszy strukturalnych opartego na szacowaniu wysokości wskaźnika średniego unijnego PKB dla regionu z poziomu NUTS II okazało się, iż państwa te i ich regiony stały się głównymi beneficjentami unijnej pomocy w zakresie wsparcia rozwoju regionalnego. Aby równoważyć interesy finansowe państw UE w korzystaniu z unijnego budżetu, od 2007 r. w ramach realizacji założenia, jakim jest budowanie konkurencyjnej gospodarki europejskiej, zdefiniowanego w strategii lizbońskiej, dostęp do funduszy strukturalnych uzyskały także regiony o wysokim poziomie rozwoju, które jednocześnie zdolne były do efektywnego wykorzystywania funduszy strukturalnych w celu podnoszenia konkurencyjności swoich gospodarek ${ }^{5}$. Wprowadzono jednakże warunek wykazania proinwestycyjnego charakteru realizowanych w nich projektów i ponoszonych wydatków.

Mimo terytorializacji procesów rozwoju regiony europejskie podlegają tym samym siłom sprawczym i wyzwaniom o charakterze globalnym, które mogą stanowić istotne

2 Por. T. Drożyński, Efektywność polityki spójności UE i jej wptyw na rozwój regionów, [w:] Międzynarodowe stosunki gospodarcze - integracja regionalna $w$ Europie i na świecie, red. T. Sporek, Katowice 2012, s. 70-71, Studia Ekonomiczne. Zeszyty Naukowe Wydziatowe Uniwersytetu Ekonomicznego w Katowicach, 123 oraz Regional Innovation Scoreboard 2017, European Commission, [online] https:// www.ewi-vlaanderen.be/sites/default/files/imce/ris2017_executive_summmary_en.pdf, 25 VII 2020.

3 A. Cappelen, F. Castellacci, J. Fagerberg, B. Verspagen, The Impact of EU Regional Support on Growth and Convergence in the European Union, "Journal of Common Market Studies" 2003, vol. 41, nr 4.

4 T.G. Grosse, Polityka spójności w dobie kryzysu strefy euro, „Studia Regionalne i Lokalne” 2016, nr 1(63); M. Michalewska-Pawlak, Wielopoziomowy system zarządzania politykami regionalnymi państw cztonkowskich Unii Europejskiej jako rezultat procesów europeizacyjnych na przyktadzie Polski, [w:] Europeizacja polityk publicznych w Polsce, red. R. Riedel, Opole 2016 oraz J. Bachtler, C. Mendez, Who Governs EU Cohesion Policy? Deconstructing the Reforms of the Structural Funds, „Journal of Common Market Studies" 2007, vol. 45, nr 3.

5 I. Begg, The Future of Cohesion Policy in Richer Regions, „Working Papers. A series of short papers on regional research and indicators produced by the Directorate-General for Regional Policy" 2009, nr 3, s. 8, [online] http://ec.europa.eu/regional_policy/sources/docgener/work/2009_03_richer.pdf, 25 VII 2020. 
bariery dla ich rozwoju. Wśród nich należy wymienić niekorzystne zmiany demograficzne w postaci starzenia się społeczeństwa europejskiego. Chociaż proces ten w wymiarze regionalnym dotyczy w większym stopniu terenów wiejskich, także miasta mimo napływu ludzi młodych, związanego z lepszymi perspektywami edukacyjnymi i większymi możliwościami zatrudnienia - borykają się z problemem braku odpowiedniej ilości i jakości zasobów siły roboczej, niezbędnych dla rozwoju regionalnych rynków pracy. Dysproporcje w tym aspekcie są dostrzegalne również pomiędzy regionami wschodnimi i zachodnimi oraz północnymi i południowymi, w ramach struktur terytorialnych poszczególnych państw członkowskich $\mathrm{UE}^{6}$.

Znaczące różnice we wzroście gospodarczym pomiędzy regionami, wyrażone w poziomie średniego unijnego PKB, występują także w odniesieniu do stopnia aktywności zawodowej ludności w wieku produkcyjnym ${ }^{7}$. Dostępne zasoby kapitału ludzkiego nie są w pełni wykorzystywane, o czym świadczy chociażby wysoka stopa bezrobocia wśród ludzi młodych, w niektórych regionach przekraczająca dwukrotnie poziom bezrobocia wśród innych grup wiekowych ${ }^{8}$. Pojawia się swoistego rodzaju paradoks polegający na tym, że regiony z jednej strony dotknięte są deficytem siły roboczej na rynku pracy, z drugiej zaś odnotowuje się niski poziom zatrudnienia ludzi rozpoczynających życie zawodowe. Może to być wynikiem, miedzy innymi, niedostosowania systemów edukacji i programów kształcenia do potrzeb regionalnych rynków pracy. Opisane wyżej zjawisko ma z kolei wpływ na niską konkurencyjność regionów unijnych, zarówno w wymiarze europejskim, jak i globalnym. Problem ten dotyczy głównie regionów usytuowanych w południowej, środkowej i wschodniej części Europy ${ }^{9}$. Jednak presja konkurencyjności światowej powoduje, że nawet regiony najbardziej rozwinięte gospodarczo, efektywnie korzystające z posiadanych zasobów muszą nieustannie finansować rozwój wiedzy, innowacje oraz wykorzystanie nowych technologii w swoich gospodarkach. Proces ten inspiruje Unię Europejską do inwestowania w te nowe przedsięwzięcia, chociażby poprzez zwiększanie wydatków na badania i rozwój ${ }^{10}$.

Obok wyzwań o charakterze społecznym i ekonomicznym wpływ na poziom rozwoju regionów i jakość życia ich mieszkańców mają także kwestie dotyczące stanu środowiska naturalnego, zapobiegania zmianom klimatu, zrównoważonego korzystania z zasobów oraz źródeł pozyskiwania i sposobów wykorzystania energii. Mają one charakter

6 Population Statistics at Regional Level 2017, Eurostat, [online] http://ec.europa.eu/eurostat/sta tistics-explained/index.php/Population_statistics_at_regional_level\#Population_change, 24 VII 2020.

7 GDP at Regional Level, Eurostat, [online] http://ec.europa.eu/eurostat/statistics-explained/index. php/GDP_at_regional_level, 24 VII 2020.

8 Unemployment Statistics, Eurostat, [online] http://ec.europa.eu/eurostat/statistics-explained/index. php/Unemployment_statistics\#Youth_unemployment, 18 I 2019.

9 European Regional Competitiveness Index 2016, European Commission, [online] http://ec.europa.eu/ regional_policy/en/information/maps/regional_competitiveness/, 19 I 2019.

10 J. Szlachta, Terytorializacja jako wyzwanie polityki rozwoju-perspektywa europejska, „Studia KPZK” 2018, vol. 184, s. 13. 
zintegrowany i horyzontalny, ponieważ oddziałują niemal na wszystkie aspekty rozwoju społecznego i gospodarczego regionów.

Diagnoza problemów i wyzwań rozwojowych stojących przed europejskimi regionami zawarta została w szóstym raporcie kohezyjnym opublikowanym w lipcu 2014 r., który wskazuje także na konkretne kierunki inwestowania w czynniki wtórne wzrostu, wśród których wymienione zostały: kapitał publiczny, lepsza dostępność, kapitał ludzki, innowacje, jakość instytucjonalna oraz aglomeracje i klastry ${ }^{11}$.

Wyzwania, wspólne dla wszystkich regionów europejskich niezależnie od poziomu ich PKB, mające wpływ na dynamikę ich rozwoju, wymagają interwencji na różnych poziomach terytorialnej organizacji. W latach 2014-2020 na realizacje celów rozwojowych państw i regionów UE przeznaczonych zostało 351,8 mld euro, co stanowi blisko jedną trzecią całego unijnego budżetu. Niemniej jednak warto zwrócić uwagę, iż wydatki te zmniejszono w stosunku do poprzedniej perspektywy 2007 2013 o ponad $8 \%{ }^{12}$. W konsekwencji recesji gospodarczej oraz rosnącego zadłużenia publicznego państw członkowskich, w dużej mierze mającego charakter strukturalny, a wywołanego między innymi kryzysem finansowym z 2008 r., od 2014 r. Unia Europejska dąży do efektywniejszego wykorzystania funduszy strukturalnych, których zadaniem jest inwestowanie $\mathrm{w}$ dziedziny tematyczne stanowiące wspólne wyzwania rozwojowe dla wszystkich regionów, przy czym cel nadrzędny stanowi innowacyjność i konkurencyjność gospodarcza ${ }^{13}$. Jak wskazane zostanie w dalszej części artykułu, ewolucji podlegają także instytucjonalne warunki w zakresie efektywnego korzystania z funduszy strukturalnych, zarówno w zakresie poprawy zakładanych rezultatów interwencji, jak i wdrożenia reform niezbędnych do sprawnego funkcjonowania systemów zarządzania rozwojem. Osiągane dzięki inwestycjom rezultaty mają być mierzone za pomocą wskaźników efektywności osiągania celów ${ }^{14}$, które w sposób całościowy będzie można zweryfikować po zakończeniu okresu rozliczeniowego obecnej perspektywy finansowej, czyli na początku roku 2024. Warto zauważyć, iż konkretne wartości wskaźników określające efekty realizowanej polityki, np. odnoszące się do liczby nowo utworzonych firm albo opracowanych innowacyjnych produktów, zostały przyjęte w każdym programie operacyjnym finansowanym $\mathrm{z}$ funduszy strukturalnych, jednak ich rzeczywista wartość i poziom realizacji zweryfikowane będą w dalszej perspektywie czasowej. Ewaluacja efektów tak sformułowanej polityki powinna mieć charakter perspektywiczny i brać pod uwagę trwałość osiągniętych rezultatów.

11 Inwestycje na rzecz wzrostu gospodarczego i zatrudnienia. Promowanie rozwoju i dobrego rzadzenia w regionach UE i miastach. Szósty raport na temat spójności gospodarczej, spotecznej i terytorialnej, Komisja Europejska, Bruksela 2014, s. 203-204.

12 T.G. Grosse, Polityka spójności..., s. 8.

13 M. Świstak, Polityka regionalna Unii Europejskiej jako polityka publiczna. Wobec potrzeby optymalizacji publicznego dziatania, Kraków 2018, s. 104-105.

14 Inwestycje na rzecz wzrostu gospodarczego i zatrudnienia..., s. XXI. 


\section{INWESTYCYJNY CHARAKTER CELÓW POLITYKI REGIONALNEJ PO $2014 \mathrm{R}$.}

Realizowana od 2007 r. polityka regionalna UE adresowana jest do wszystkich regionów, bez względu na poziom rozwoju, a jej celem jest wspomaganie zatrudnienia, konkurencyjności przedsiębiorstw, wzrostu gospodarczego i zrównoważonego rozwoju, a także podniesienie jakości życia obywateli. Obok stopniowego rozszerzenia katalogu regionów uprawnionych do otrzymywania wsparcia z funduszy strukturalnych zaobserwować można w polityce regionalnej UE proces koncentracji na realizacji tematycznych celów priorytetowych, wspólnych dla wszystkich regionów.

Zmniejszenie liczby priorytetowych celów polityki regionalnej w okresie 20002006, w porównaniu z wcześniejszą perspektywą finansową, stwarzających ramy dla konstruowania programów rozwojowych miało na celu zwiększenie geograficznej koncentracji realizowanych programów i wzmocnienie efektywności podejmowanych działań oraz ułatwienie osiągania zamierzonych rezultatów interwencji funduszy strukturalnych. W ramach celu 1., o charakterze regionalnym, zaplanowano wsparcie rozwoju i dostosowania strukturalnego regionów opóźnionych w rozwoju. Cel 2. dedykowany był regionom UE niezakwalifikowanym do obszarów celu 1., które stojąc w obliczu poważnych problemów strukturalnych, wykazały zasadność wsparcia dzialań ze środków polityki regionalnej UE na rzecz ich konwersji gospodarczej. W ramach celu 3., który jako jedyny miał charakter horyzontalny, wspierano dostosowanie i modernizację polityk i systemów kształcenia, szkolenia i zatrudnienia, ukierunkowanych na założenia strategii lizbońskiej. Już w latach 2000-2006 przede wszystkim cel 3. można było określić jako inwestycyjny, ponieważ orientował się na działania wyprzedzające, zmierzające do koordynacji aktywności na rzecz kształcenia i zatrudniania oraz przewidywania zmian zachodzących w gospodarce i dostosowywania się do nich pracowników.

Nowe sformułowanie celów polityki regionalnej UE na lata 2007-2013 stało się dowodem na wprowadzenie zmian w pojmowaniu i realizacji założenia spójności społecznej i gospodarczej. Odnowiona strategia lizbońska, utrzymując priorytet podnoszenia konkurencyjności gospodarki UE, położyła nacisk na konieczność działań wzmacniających wzrost gospodarczy i zatrudnienie. Co znamienne, hasła strategii zostały bezpośrednio przeniesione do nazw poszczególnych rozdziałów ram perspektywy finansowej 2007-2013. Utrzymano priorytety celu 1., mającego dokładnie takie same założenia jak w poprzednich perspektywach finansowych, jednocześnie nadając mu nazwę „Konwergencja”. Działania ukierunkowano na przyspieszenie rozwoju i wyrównywanie szans najbiedniejszych państw członkowskich i ich regionów, przez poprawę warunków wzrostu i zatrudnienia.

Cel 2. był zorientowany na zwiększanie konkurencyjności, zatrudnienia i atrakcyjności wszystkich regionów nieobjętych zakresem interwencji w ramach celu 1. Wsparcie finansowe ukierunkowano na przygotowanie gospodarek i społeczności regionalnych do zachodzących zmian gospodarczych i społecznych, na promowanie innowacyjności, 
przedsiębiorczości, ochrony środowiska, dostępności, zdolności adaptacyjnych oraz na rozwój rynków pracy sprzyjających integracji społecznej. W ramach celu 3. działania skoncentrowane były na wzmacnianiu współpracy terytorialnej o charakterze transgranicznym, międzyregionalnym i transnarodowym.

Tabela1. Ewolucja celów polityki regionalnej w strukturze wieloletnich ram finansowych 2000-2020

\begin{tabular}{|c|c|c|c|c|c|}
\hline $2000-2006$ & $\begin{array}{c}\text { Źródło } \\
\text { finanso- } \\
\text { wania }\end{array}$ & $2007-2013$ & $\begin{array}{c}\text { Źródło } \\
\text { finanso- } \\
\text { wania }\end{array}$ & 2014-2020* & $\begin{array}{l}\text { Źródło } \\
\text { finanso- } \\
\text { wania** }^{* *}\end{array}$ \\
\hline $\begin{array}{l}\text { Cel } 1 . \\
\text { (regionalny) - } \\
\text { wspieranie rozwo- } \\
\text { ju i dostosowania } \\
\text { strukturalnego } \\
\text { regionów opóźnio- } \\
\text { nych w rozwoju }\end{array}$ & $\begin{array}{l}\text { EFRR, } \\
\text { EFS, } \\
\text { FEOGA, } \\
\text { FIUR }\end{array}$ & $\begin{array}{l}\text { Cel } 1 . \\
\text { (regionalny) - } \\
\text { Konwergencja }\end{array}$ & $\begin{array}{l}\text { EFRR, } \\
\text { EFS, FS }\end{array}$ & $\begin{array}{l}\text { Cel 1. - } \\
\text { badania } \\
\text { naukowe } \\
\text { i innowacje }\end{array}$ & $\begin{array}{l}\text { EFRR, } \\
\text { EFS }\end{array}$ \\
\hline $\begin{array}{l}\text { Cel } 2 . \\
\text { (regionalny) - } \\
\text { wspieranie gospo- } \\
\text { darczej i spo- } \\
\text { łecznej konwer- } \\
\text { sji obszarów } \\
\text { stojących w ob- } \\
\text { liczu problemów } \\
\text { strukturalnych }\end{array}$ & $\begin{array}{l}\text { EFRR, } \\
\text { EFS }\end{array}$ & $\begin{array}{l}\text { Cel } 2 . \\
\text { (regionalny) - } \\
\text { konkurencyj- } \\
\text { ność regionalna } \\
\text { i zatrudnienie }\end{array}$ & $\begin{array}{l}\text { EFRR, } \\
\text { EFS }\end{array}$ & $\begin{array}{l}\text { Cel 2.- } \\
\text { technologie } \\
\text { informacyjne i } \\
\text { komunikacyjne }\end{array}$ & $\begin{array}{l}\text { EFRR, } \\
\text { EFS }\end{array}$ \\
\hline \multirow[t]{2}{*}{$\begin{array}{l}\text { Cel } 3 . \\
\text { (horyzontalny) - } \\
\text { wspieranie dosto- } \\
\text { sowania i moder- } \\
\text { nizacji polityk i } \\
\text { systemów kształ- } \\
\text { cenia, szkolenia } \\
\text { i zatrudnienia }\end{array}$} & EFS & $\begin{array}{l}\text { Cel } 3 . \\
\text { (regionalny) - } \\
\text { europejska } \\
\text { współpraca } \\
\text { terytorialna }\end{array}$ & EFRR & $\begin{array}{l}\text { Cel 3. - } \\
\text { większa konku- } \\
\text { rencyjność ma- } \\
\text { łych i średnich } \\
\text { przedsiębiorstw }\end{array}$ & EFRR \\
\hline & & & & $\begin{array}{l}\text { Cel 4. - przejście } \\
\text { na gospodarkę } \\
\text { niskoemisyjną }\end{array}$ & EFRR \\
\hline
\end{tabular}

Źródło: opracowanie własne na podstawie M. Klimowicz, Ewolucja celów polityki regionalnej Unii Europejskiej w procesie integracji gospodarczej, [w:] Procesy integracyjne $i$ dezintegracyjne $w$ Europie. Podręcznik akademicki, red. A. Pacześniak, M. Klimowicz, Wrocław 2014, s. 203-236.

* W tabeli nr 1 przedstwione zostały cztery główne z jedenastu celów tematycznych polityki regionalnej 2014-2020. Pozostałe siedem dotyczy: promowania działań dostosowawczych do zmian klimatu oraz zapobiegania ryzyku zmiany klimatu i zarządzania nim; zachowania i odnowy środowiska oraz promowania efektywnej gospodarki odpadami; promowania zrównoważonego transportu oraz usuwania niedoborów przepustowości w działaniach najważniejszych infrastruktur sieciowych; promowania trwałego i wysokiej jakości zatrudnienia oraz wspierania mobilności siły roboczej; promowania włączenia społecznego oraz zwalczania ubóstwa i wszelkich form dyskryminacji; inwestowania w kształcenie, szkolenie oraz szkolenie zawodowe na rzecz zdobywania umiejętności i uczenia się przez całe życie; wzmacniania zdolności instytucjonalnych instytucji publicznych i zainteresowanych stron oraz sprawności administarcji publicznej. 
Rozporządzenie Parlamentu Europejskiego i Rady (UE) nr 1303/2013 z dnia 17 grudnia 2013 r. ustanawiające wspólne przepisy dotyczące Europejskiego Funduszu Rozwoju Regionalnego, Europejskiego Funduszu Spotecznego, Funduszu Spójności, Europejskiego Funduszu Rolnego na rzecz Rozwoju Obszarów Wiejskich oraz Europejskiego Funduszu Morskiego i Rybackiego oraz ustanawiające przepisy ogólne dotyczace Europejskiego Funduszu Rozwoju Regionalnego, Europejskiego Funduszu Spotecznego, Funduszu Spójności i Europejskiego Funduszu Morskiego i Rybackiego oraz uchylająe rozporzadzenie Rady (WE) nr1083/2006, Dz.U. L 347 z 20.12.2013, s. 343 .

** W ramach perspektyw finasowych 2007-2013 oraz 2014-2020 w źródłach finasowania celów polityki regionalnej nie uwzględniono Europejskiego Funduszu Rolnego na Rzecz Rozwoju Obszarów Wiejskich. Wynika to z faktu reform polityki regionalnej i rolnej UE wdrażanych od 2007 r., zgodnie z którymi fundusz finasujacy rozwój regionów wiejskich został włączony w struktury drugiego filara wspólnej polityki rolnej UE. Szerzej patrz: M. Michalewska-Pawlak, Zarządzanie rozwojem obszarów wiejskich w Polsce w warunkach integracji europejskiej, Warszawa 2015, s. 93-97.

Potrzeba dalszych zmian w polityce regionalnej w kierunku umocnienia jej inwestycyjnego charakteru wynikała ze sprawozdań, analiz oraz opracowań eksperckich, zawierających rekomendacje dla inicjatorów reform ${ }^{15}$. Debata nad przyszłością polityki rozwoju regionalnego prowadzona była m.in. na podstawie raportu Program dla zreformowanej polityki spójności, przygotowanego przez zespół ekspertów pod przewodnictwem Fabrizia Barki, czy kolejnych sprawozdań dotyczących spójności gospodarczej, społecznej i terytorialnej publikowanych przez Komisję Europejską, przygotowanych pod kierownictwem Maria Montiego i Jean-Claude'a Junckera. Wiele z tych dokumentów i opracowań w sposób krytyczny odnosiło się zarówno do efektów osiąganych dzięki realizacji omawianej polityki, jak i samego procesu jej wdrażania. W raporcie Montiego opublikowanym w 2017 r. znalazła się zapowiedź redukcji wydatków na projekty o niskiej wartości dodanej, w tym z zakresu polityki regionalnej, w świetle istniejących wyzwań budżetowych i ogólnego kryzysu procesów integracji europejskiej. Podobne wnioski zawiera Biata ksiega w sprawie przysztości Europy. Refleksje i scenariusze dotyczace przysztości UE-27 do 2025 r. opracowana pod przewodnictwem Jean-Claude'a Junckera ${ }^{16}$.

Wzrost znaczenia paradygmatu inwestycyjnego w polityce regionalnej Unii Europejskiej po 2014 r. wynikał z modyfikacji jej głównych celów, opierającej się na skorelowaniu priorytetów polityki regionalnej z kierunkami polityki gospodarczej. $\mathrm{Na}$ lata 2014-2020 zaplanowana została realizacja jedenastu celów tematycznych zorientowanych na wykorzystanie regionalnych potencjałów rozwojowych ${ }^{17}$. Wprowadzono przy tym zasadę koncentracji tematycznej, która przewiduje, że zgodnie z przyjętym podziałem regiony: najsłabiej rozwinięte, przejściowe oraz wysoko rozwinięte mają obowiązek wydatkować odpowiednio minimum: 50\%, 60\% oraz $80 \%$ przeznaczonej dla nich puli EFRR na realizację dwóch z czterech głównych priorytetów

15 M. Kolczyński, P. Żuber, Nowy paradygmat rozwoju - najnowsze trendy i perspektywy polityki regionalnej, Warszawa 2011, s. 7.

16 J. Szlachta, J. Zaleski, Strategiczne wybory polityki spójności UE po roku 2020 w świetle dokumetów programowych Komisji Europejskiej, „Studia KPZK” 2018, vol. 183, s. 215-216.

17 M.W. Kozak, Polityka spójności 2014-2020: rewolucja, reforma czy utrzymanie status quo?, „Studia Regionalne i Lokalne" 2015, $\mathrm{nr}$ 4(62), s. 15. 
tematycznych ${ }^{18}$. Wyznaczone obszary takie jak innowacje, przedsiębiorczość oraz nowe technologie związane są z budową pozycji konkurencyjnej wszystkich jednostek terytorialnych otrzymujących pomoc, natomiast kwestie dotyczące zarządzania energią mają wpływ zarówno na gospodarkę, społeczeństwo, jak i na środowisko.

Zmiana ukierunkowania instrumentów polityki spójności, w tym polityki regionalnej, z prorozwojowości na proinwestycyjność została dokonana w kontekście osiągania celów strategii Europa 2020. Polityka regionalna zapewnia bowiem ramy inwestycyjne niezbędne do realizacji priorytetów rozwoju inteligentnego, zrównoważonego i sprzyjającego włączeniu społecznemu (zdefiniowanego w strategii ${ }^{19}$ ). Jej przedsięwzięcia mają za zadanie ułatwiać osiąganie wyżej wymienionych celów, uzupełniając unijną politykę w zakresie kształcenia, zatrudnienia, energii, środowiska, jednolitego rynku oraz badań naukowych i innowacji.

Dostosowanie polityki regionalnej do celów strategii Europa 2020 jest realizowane przede wszystkim poprzez Wspólne ramy strategiczne, opracowane na poziomie UE, którymi państwa członkowskie mają obowiązek się kierować przy tworzeniu własnych strategii inwestowania oraz umów o partnerstwie, w ramach których każde z nich musi określać cele, główne priorytety i wymagania instytucjonalne, jednocześnie przyznając Komisji bardziej strategiczną rolę i ukierunkowując politykę na wyniki osiągane dzięki interwencji funduszy strukturalnych.

Kolejnym skutkiem wprowadzenia paradygmatu inwestycyjnego było poddanie środków wydatkowanych w ramach polityki regionalnej znacznie silniejszemu rygorowi nadzoru i monitoringu ${ }^{20}$. Zastosowana została zasada warunkowości ex-ante, zgodnie z którą wypłata funduszy strukturalnych jest powiązana ze spełnieniem przez państwa szeregu warunków wstępnych, mających wplyw na efektywne zarządzanie wydatkowaniem funduszy, a tym samym na osiągane rezultaty. Zestaw owych warunków jest każdorazowo odmienny dla każdego państwa członkowskiego i zależy od sytuacji wyjściowej, w jakiej znajdowały się obszary wyznaczone do reformowania. Innym rozwiązaniem wzmacniającym orientację inwestycyjną jest wprowadzenie rezerwy na wykonanie, która może działać mobilizująco na państwa i regiony w zakresie tempa realizacji programów operacyjnych oraz starań na rzecz osiągania zakładanych rezultatów ${ }^{21}$.

$\mathrm{Na}$ podstawie propozycji KE dotyczących rozwiązań finansowych w ramach perspektywy 2021-2027 można sformułować tezę, iż wymiar inwestycyjny w interwencji funduszy strukturalnych będzie nadal wzmacniany. Wynika z nich bowiem, że środki dedykowane polityce spójności zostaną zmniejszone o ok. 10\% w stosunku do budżetu

18 Towards Social Investment for Growth and Cohesion - including implementing the European Social Fund 2014-2020, European Commission, 20 II 2013, s. 13, [online] http://eurlex.europa.eu/LexUriServ/LexUriServ.do?uri=COM:2013:0083:FIN:en:PDF, 20 VII 2020.

19 Europa 2020. Strategia na rzecz inteligentnego i zrównoważonego rozwoju sprzyjajacego wtączeniu spotecznemu, Komisja Europejska, Bruksela 2010.

20 P. McCann, R. Ortega-Argilés, Redesigning and Reforming European Regional Policy: The Reasons, the Logic, and the Outcomes, „International Regional Science Review” 2012 oraz T.G. Grosse, Polityka spójności..., s. 8.

21 Towards Social..., s. 9. 
realizowanego w obecnej perspektywie finansowej ${ }^{22}$. Stanowi to logiczną konsekwencję zarówno procesu wyjścia Wielkiej Brytanii z UE 1 lutego 2020 r., która jako największy płatnik netto finansowała ok. $12 \%$ unijnego budżetu, jak i refleksji nad wynikami dotychczas wdrażanego modelu polityki regionalnej ${ }^{23}$. Zaistniała sytuacja oznacza konieczność rewizji analizowanej polityki pod kątem weryfikacji skuteczności w osiąganiu założonych celów, a także dalszej koncentracji na kluczowych priorytetach rozwojowych i efektywnym gospodarowaniu środkami finansowymi. Wpływ brexitu na finansowanie polityki regionalnej UE w aspekcie redukcji jej wydatków będzie jednym z głównych wyzwań perspektywy finansowej 2021-202724.

Po 2020 r. polityka wsparcia regionów UE bazować będzie nadal na celach tematycznych, priorytetowych w perspektywie całej UE, z tym że zaproponowane zostaną zmiany w kierunku ograniczenia ich liczby do maksymalnie pięciu ${ }^{25}$. Mają tu się znaleźć: innowacje i przedsiębiorczość, walka ze zmianami klimatu, mobilność i regionalne połączenia teleinformatyczne, integracja społeczna oraz partycypacja obywatelska ${ }^{26}$. Ostatni temat priorytetowy, dotąd marginalnie występujący, głównie w ramach interwencji EFS i projektów na rzecz integracji społecznej i zawodowej, może stać się jednym z najważniejszych, co potwierdza tezę sformułowaną we wstępie artykułu, zakładającą, że polityka regionalna UE ma odpowiadać na kluczowe wyzwania, przed którymi w danym okresie stoją europejskie regiony. KE proponuje rozszerzenie kryteriów podziału funduszy strukturalnych pomiędzy państwa i regiony, obejmujące, obok tradycyjnie stosowanych wskaźników takich jak PKB czy liczba ludności, także warunki odnoszące się do sytuacji społecznej czy środowiskowej określonych terytoriów. Zatem można się spodziewać, że lista regionów uprawnionych do otrzymywania maksymalnego wsparcia oraz kierunki dystrybucji środków funduszy strukturalnych, przeznaczonych na inwestycje podnoszące konkurencyjności regionów, ulegną zasadniczym zmianom po $2020 \mathrm{r}$.

\section{ZNACZENIE EUROPEJSKIEGO FUNDUSZU ROZWOJU REGIONALNEGO W INWESTOWANIU WE WZROST GOSPODARCZY REGIONÓW}

EFRR od początku swojego istnienia miał na celu udzielanie wsparcia regionom odnotowującym bariery rozwojowe. Od 2014 r. interwencja tego funduszu koncentruje się głównie na budowaniu pozycji konkurencyjnej zarówno regionów słabo, średnio, jak

22 M. Makowska, Polityka spójności po 2020 r. - ostrożna próba reformy, „Biuletyn PISM” 2018, nr 107(1680), [online] http://www.pism.pl/files/?id_plik=24702, 20 I 2019.

23 J. Bachtler, I. Begg, Beyond Brexit: Reshaping Policies for Regional Development in Europe, „Papers in Regional Science" 2018, vol. 97, nr 1, s. 152.

24 J. Szlachta, J. Zaleski, Challenges of Future EU Cohesion Policy, „Gospodarka Narodowa” 2017, nr 5(291), s. 33.

25 M. Makowska, Polityka spójności po 2020...

26 M.Michalewska-Pawlak, Wptyw wieloletnich ram finansowych 2021-2027 Unii Europejskiej na zarzadzanie rozwojem regionalnym w Polsce, „Polityka i Społeczeństwo” 2019, nr 3(17), s. 72. 
i wysoko rozwiniętych, w ograniczonym zaś stopniu na transferach mających stanowić rekompensatę dla obszarów problemowych ${ }^{27}$. Jako główny instrument wsparcia rozwoju gospodarczego regionów o charakterze inwestycyjnym należy wskazać strategie inteligentnych specjalizacji (RIS3). Umożliwiają one, dzięki zaangażowaniu środków EFRR, efektywne wykorzystanie zróżnicowanych potencjałów wewnętrznych regionów UE poprzez koncentrację na inwestowaniu w rozwój kluczowych dziedzin regionalnych gospodarek. Warto dodać, iż w perspektywie finansowej 2014-2020 przygotowanie takich strategii przez regiony jest warunkiem ex-ante uzyskania finansowania z EFRR ${ }^{28}$. Programy mają bazować na generowaniu i wykorzystaniu regionalnych zasobów wiedzy i innowacji dla kształtowania przewagi konkurencyjnej regionalnych firm, które mogą uzyskać dofinansowanie z EFRR na realizację swoich przedsięwzięć gospodarczych ${ }^{29}$. RIS3 zakładają szerokie zaangażowanie sektora prywatnego, nie tylko w ich wdrożenie, ale także w proces wyznaczenia priorytetowych obszarów inwestowania. Zatem EFRR ma się przyczynić do wykorzystania różnych zasobów wspomnianego sektora - od wiedzy, przez doświadczenia, po środki finansowe - na realizację założeń RIS3. Wprowadzanie strategii przy dotacjach z EFRR niesie ze sobą także konkretne znacznie dla potencjalnych beneficjentów, ponieważ premiuje tylko projekty wpisujące się swoim celem w obszar tematyczny inteligentnych specjalizacji.

W aktualnej perspektywie finansowej wsparcie dla rozwoju przedsiębiorstw obejmuje nie tylko dotacje wypłacane ze środków EFRR, ale także instrumenty finansowe posiadające odnawialny charakter, które mają być oparte na mechanizmie dźwigni finansowej ${ }^{30}$. Takie rozwiązanie, w przeciwieństwie do wsparcia udzielanego $\mathrm{w}$ formie dotacji bezzwrotnych, umożliwia generowanie wartości dodanej w postaci wielokrotnego wykorzystania środków EFRR na realizację projektów inwestycyjnych przeprowadzanych przez przedsiębiorstwa. Zwrotne instrumenty finansowe w polityce UE stosowane są wobec przedsięwzięć zasadnych rynkowo i finansowo wykonalnych, które otrzymują niewystarczające środki ze źródeł rynkowych ${ }^{31}$. Może mieć to kluczowe znacznie dla podmiotów gospodarczych, w perspektywie postępującej redukcji wydatków na realizację prorozwojowych polityk publicznych. Korzystanie z pomocy zwrotnej czy gwarancji przez przedsiębiorców ma jednocześnie szansę przyczynić się do poprawy ich własnych mikroekonomicznych strategii inwestowania i wzrostu efektywności uzyskiwanych rezultatów z zainwestowanych środków.

27 A. Noworól, Zarządzanie rozwojem w kontekście nowej polityki regionalnej, [w:] Zarządzanie publiczne: koncepcje, metody, techniki, red. A. Frączkiewicz-Wronka, Katowice 2013, s. 159, Studia Ekonomiczne. Zeszyty Naukowe Wydziatowe Uniwersytetu Ekonomicznego w Katowicach, 169. Rozporzadzenie Parlamentu Europejskiego i Rady (UE) nr 1303/2013..., s. 338.

29 A. Wiktorska-Święcka, M. Klimowicz, M. Michalewska-Pawlak, Innowacje we wspótzarządzaniu rozwojem regionalnym. Praktyka instytucjonalna $w$ wybranych polskich regionach. Wrocław-Warszawa 2017, s. 199.

T.G. Grosse, Polityka spójności..., s. 10.

31 A. Bartoszewicz, Instrumenty finansowe realizacji polityki spójności Unii Europejskiej, [w:] Perspektywy polityki gospodarczej, red. J. Stacewicz, Warszawa 2017, s. 189, Prace i materiaty Instytutu Rozwoju Gospodarczego $S G H, 99$. 
Inwestycyjny charakter EFRR odzwierciedla się w terytorialnym ukierunkowaniu jego działalności, przede wszystkim na obszary generujące największy wzrost gospodarczy, czyli miasta. Od 2014 r. państwa członkowskie są zobligowane do wdrażania zintegrowanych i innowacyjnych inwestycji w miastach i ich obszarach funkcjonalnych, czemu służyć ma wydatkowanie minimum 5\% budżetu EFRR na tego typu działania. Towarzyszy temu implementacja nowego instrumentu zarządzania rozwojem miast i ich obszarów funkcjonalnych, jakim są Zintegrowane Inwestycje Terytorialne ${ }^{32}$.

Inwestycyjny charakter EFRR skupia się przede wszystkim na osiąganiu celu strategii Europa 2020 zdefiniowanego jako rozwój inteligentny ${ }^{33}$. Jego realizacja zakłada wzrost nakładów na badania naukowe i rozwój jako źródło innowacji regionalnych gospodarek. Dzięki inwestycjom EFRR ma nastąpić poprawa jakości badań naukowych i wykorzystanie ich rezultatów w rozwoju gospodarczym regionów oraz budowaniu ich przewagi konkurencyjnej. Warto jednak zauważyć, że proces ten jest warunkowany szeregiem czynników natury instytucjonalnej, kulturowej, organizacyjnej, prawnej, które powodują, iż nakłady w ramach EFRR dają pozytywne efekty w postaci zróżnicowanej dynamiki wzrostu innowacyjności i konkurencyjności poszczególnych regionów $\mathrm{UE}^{34}$.

\section{EUROPEJSKI FUNDUSZ SPOŁECZNY JAKO INSTRUMENT WSPARCIA INWESTYCJI SPOEECZNYCH W REGIONACH UNII EUROPEJSKIEJ}

Europejski Fundusz Społeczny w okresie 2014-2020 stanowi główny instrument wdrażania unijnego paradygmatu inwestycyjnego w wymiarze społecznym. Istotne znaczenie w kontekście polityki regionalnej Unii Europejskiej ma promowanie inwestycji społecznych jako narzędzia walki z ubóstwem, wykluczeniem społecznym i bezrobociem, co czyni je jednymi z podstawowych celów działań w sferze społecznej ${ }^{35}$. Dzięki inwestycjom społecznym doskonali się obecne i przyszłe umiejętności zasobów kapitału ludzkiego, a oprócz efektów natychmiastowych polityka inwestycyjna ma również trwałe skutki, oferując w ciągu dłuższego czasu korzyści gospodarcze i społeczne, w szczególności w zakresie poprawy perspektyw zatrudnienia i dochodów z pracy. Podstawą paradygmatu inwestycji społecznych w Europie jest założenie, iż wyzwania społeczeństw postindustrialnych, takie jak starzenie się populacji, zmiana struktury gospodarstw domowych oraz rozwój gospodarki opartej na wiedzy, sprawiają, iż jednostka napotyka w trakcie cyklu życia wiele problemów i wyzwań, które wymagają zarówno

32 Rozporzadzenie Parlamentu Europejskiego i Rady (UE) nr 1301/2013 z dnia 17 grudnia 2013 r. wsprawie Europejskiego Funduszu Rozwoju Regionalnego i przepisów szczególnych dotyczących celu „Inwestycje na rzecz wzrostu i zatrudnienia" oraz w sprawie uchylenia rozporzaddzenia (WE) nr 1080/2006, Dz.U. L 347 z 20.12.2013, s. 291, 296.

33 Europa 2020. Strategia na rzecz...

34 European Regional...

35 A. Wiktorska-Święcka, M. Klimowicz, M. Michalewska-Pawlak, D. Moroń, Inwestycje spoteczne jako nowy paradygmat polityk publicznych w Unii Europejskiej, Warszawa 2017, s. 10. 
od niej, jak i od instytucji państwowych, społecznych i ekonomicznych poszukiwania nowych sposobów ich rozwiązywania ${ }^{36}$.

Państwa otrzymujące środki EFS są zobligowane do opracowania krajowych strategii zatrudnienia i wdrażania tych operacji, które wpisują się w paradygmat inwestycyjnej polityki społecznej ${ }^{37}$. Wprowadzanie EFS w latach 2014-2020 oparte jest na tematycznych celach, wśród których pojawiają się te dotyczące tematycznych obszarów inwestycji społecznych. Należą do nich: zwalczanie ubóstwa i wykluczenia społecznego, promowanie zatrudnienia i wsparcie mobilności siły roboczej, inwestowanie w edukację, a także rozwój umiejętności i uczenie się przez całe życie ${ }^{38}$.

Paradygmat proinwestycyjny EFS na lata 2014-2020 przejawia się w postawieniu warunków ex-ante państwom członkowskim chcącym korzystać z tego instrumentu. Dotyczą one w głównej mierze konieczności opracowania i przedstawienia dokumentów strategicznych w obszarze m.in. aktywnej polityki rynku pracy, polityki zdrowotnej, polityki aktywnego starzenia się, polityki równości, polityki na rzecz ograniczenia ubóstwa czy polityki edukacyjnej ${ }^{39}$. Dodatkowe warunki wstępne dotyczą kwestii związanych z administracyjnymi możliwościami wdrażania EFS.

Proces osiągania pięciu celów tematycznych w dziedzinach zatrudnienia, innowacji, włączenia społecznego oraz klimatu i energii został zaprojektowany tak, aby państwa członkowskie wpisały te założenia do projektowanych na poziomie krajowym działań. Co więcej, w odniesieniu do celów tematycznych Europejskiemu Funduszowi Społecznemu przypisano realizację szeregu priorytetów inwestycyjnych, którym przyporządkowano wskaźniki produktu i rezultatu. KE została zobowiązana do monitorowania postępów w osiąganiu przez państwa członkowskie wyznaczonych w strategii Europa 2020 celów, jak również realizacji priorytetów inwestycyjnych EFS. W ramach tej procedury kraje członkowskie przedkładają co dwa lata Krajowe Raporty Społeczne (KRS), zawierające informację na temat działań przez nie podjętych w obszarze zabezpieczenia społecznego, a w latach, w których nie powstają KRS, powiadamiają o stanie podjętych działań w ramach syntetycznych Strategicznych Raportów Społecznych.

Warto zwrócić uwagę, iż w 2013 r. KE opublikowała wytyczne w formie Pakietu inwestycji spotecznych (PIS), dotyczące pożądanych kierunków zmian: od tradycyjnego modelu polityki społecznej do paradygmatu inwestycyjnego ${ }^{40}$. Proponowane wy-

36 M. Klimowicz, A. Makarewicz-Marcinkiewicz, M. Michalewska-Pawlak, D. Moroń, Inwestycje spoteczne jako innowacyjna metoda zarządzania zmiana spoteczna w kontekście regionalnym i krajowym w Polsce, Kraków 2018, s. 63.

37 M. Michalewska-Pawlak, Unia Europejska wobec paradygmatu inwestycji spotecznych, „Wrocławskie Studia Politologiczne" 2017, nr 23, s. 100.

38 C. Dhéret, L. Fransen, Social Investment First! A Precondition for a Modern Social Europe, „European Policy Centre Issue Paper” 2017, nr 82, [online] http://aei.pitt.edu/85019/1/pub_7468_socialinvestmentfirst.pdf, 15 VII 2020.

39 Rozporzadzenie Parlamentu Europejskiego i Rady (UE) nr 1304/2013 z dnia 17 grudnia 2013 r. w sprawie Europejskiego Funduszu Spotecznego i uchylające rozporzadzenie Rady (WE) nr 1081/2006, Dz.U. L 347 z 20.12.2013.

40 M. Michalewska-Pawlak, Unia Europejska..., s. 100. 
tyczne mają wspierać państwa członkowskie w osiągnięciu celów strategii Europa 2020 poprzez powiązanie realizowanych reform w ramach krajowych polityk społecznych $\mathrm{z}$ wdrażaniem funduszy unijnych, w tym EFS.

PIS określił ramy polityczne służące ukierunkowaniu działań państw członkowskich na inwestycje społeczne w celu zapewnienia adekwatności i stabilności budżetów przeznaczonych na politykę społeczną, zgodnie z rezolucją Parlamentu Europejskiego w sprawie paktu na rzecz inwestycji społecznych. KE wezwała państwa należące do UE do wyznaczenia priorytetów w zakresie inwestycji społecznych i do zmodernizowania swoich systemów opieki społecznej ${ }^{41}$.

Jednocześnie PIS oparto na ramach prawnych zaproponowanych w celu realizacji polityki regionalnej w pespektywie finansowej na lata 2014-2020, a w szczególności na rozwiązaniu zakładającym wydatkowanie co najmniej 20\% środków z EFS w każdym państwie członkowskim na promowanie włączenia społecznego i zwalczanie ubóstwa ${ }^{42}$. Podkreślono w nim wagę stosowania innowacyjnych rozwiązań finansowych i prawnych oraz instytucjonalnych, takich jak: mikrofinanse, odpłatność za usługi na podstawie rezultatów, obligacje wpływu społecznego (ang. Social Impact Bonds), różne formy wsparcia przedsiębiorców społecznych oraz trójsektorowe partnerstwa (publiczno-prywatno-pozarządowe).

Jednym z najważniejszych załączników do tego dokumentu było zalecenie KE Inwestowanie $w$ dzieci. Przerwanie cyklu marginalizacji. Przedstawiono w nim zintegrowaną i wszechstronną strategię mającą na celu przeciwdziałanie ubóstwu dzieci. Istotą dokumentu jest zobowiązanie państw członkowskich UE do zapewnienia dzieciom środowiska rodzinnego dysponującego zasobami niezbędnymi do zaspokojenia ich podstawowych potrzeb. Walka z ubóstwem dzieci w oczywisty sposób wiąże się z sytuacją rodzin - decydujące znaczenie ma godna praca rodziców i godziwe wynagrodzenie, a także elastyczne warunki zatrudnienia, dzięki którym rodzice mogą łączyć aktywność zawodową z życiem rodzinnym oraz spędzać wystarczająco dużo czasu ze swoimi dziećmi ${ }^{43}$. Inwestycyjny charakter EFS odnosi się zatem do wszystkich grup społecznych, które traktowane są w kategoriach zasobów ludzkich niezbędnych do realizacji wzrostu gospodarczego w regionach. W perspektywie strategii Europa 2020 EFS ma przyczynić się do zwiększenia aktywności zawodowej Europejczyków, wzrostu poziomu i jakości wykształcenia zasobów pracy - także pod kątem zapotrzebowania regionalnych gospodarek - oraz inkluzji społecznej grup marginalizowanych bądź zagrożonych marginalizacją ${ }^{44}$.

41 F. Pazderski, Innowacyjne inwestycje spoteczne. W poszukiwaniu efektywnych odpowiedzi na wyzwania naszych czasów, Warszawa 2017, s. 9, [online] http://www.isp.org.pl/uploads/pdf/622010832.pdf, 16 I 2019.

42 Towards Social...

43 A. D’Addato, A. Williams, Inspirujace praktyki w zakresie wczesnej interwencji i profilaktyki w dziataniach na rzecz rodziny i wsparcia dla rodziców w Europie, „Dziecko krzywdzone. Teoria, badania, praktyka" 2013, vol. 12, nr 2, s. 6. 


\section{WNIOSKI}

Analiza zakresu i charakteru interwencji funduszy strukturalnych po 2014 r. w polityce regionalnej Unii Europejskiej wskazuje na stopniową marginalizację działań zorientowanych na osiąganie spójności społecznej, gospodarczej i terytorialnej regionów. Jednocześnie wzmocnieniu ulegają inwestycyjne elementy prowadzonej polityki, które mają na celu podnoszenie konkurencyjności gospodarczej wszystkich regionów, od mniej zamożnych po wysoko rozwinięte. Zarówno w aktach normatywnych, jak i dokumentach strategicznych, a także w procesie implementacji i ewaluacji interwencji finansowanych z funduszy strukturalnych w latach 2014-2020, promowane są proinwestycyjne rozwiązania ukierunkowane na generowanie korzyści gospodarczych i społecznych z zainwestowanych funduszy strukturalnych. $\mathrm{Z}$ treści kluczowych dokumentów wynika również, iż podejście inwestycyjne będzie kontynuowane w polityce regionalnej UE także po $2020 \mathrm{r}$. Przemawiają za tym propozycje wieloletnich ram finansowych artykułowane przez Komisję Europejską w odniesieniu do lat 2021-2027, jak również analiza bieżącej sytuacji politycznej związanej z wystąpieniem Wielkiej Brytanii z UE.

Zapowiedź przyszłych celów i kierunków interwencji polityki regionalnej zawiera siódmy raport kohezyjny opublikowany we wrześniu 2017 r. Można się spodziewać dalszej koncentracji na wybranych celach i priorytetach rozwojowych. W przypadku EFRR będzie to niezmiennie inwestowanie w rozwój przedsiębiorczości, innowacji i specjalizacji produkcyjnej, przy pomocy nowych technologii, a także kwestie dotyczące energii i środowiska naturalnego. W zakresie interwencji EFS działaniami priorytetowymi inwestycji społecznych prawdopodobnie będą przede wszystkim te odnoszące się do wzrostu zatrudniania i wykorzystania istniejących zasobów siły roboczej oraz edukacji i szkoleń profilowanych pod kątem potrzeb rynku pracy. Należy także oczekiwać intensyfikacji działań na rzecz integracji społecznej i zawodowej migrantów, także spoza UE, na lokalnych i regionalnych rynkach pracy ${ }^{45}$.

Osobną kwestią pozostaje pytanie, na ile skuteczne są posiadane przez KE instrumenty dyscyplinowania państw i regionów na rzecz inwestycyjnego wykorzystania przyznanych środków strukturalnych ${ }^{46}$. Bez stworzenia sprawnego systemu egzekwowania zamierzonych celów, chociażby na podstawie miarodajnych i adekwatnych wskaźników rezultatów osiąganych dzięki funduszom, uzyskane efekty dotyczące implementacji modelu rozwoju inteligentnego, zrównoważonego i sprzyjającego włączeniu społecznemu mogą być dużo mniejsze od zakładanych.

45 Mój region, moja Europa, nasza przysztość. Siódmy raport na temat spójności gospodarczej, spotecznej i terytorialnej, Komisja Europejska, Bruksela 2017, s. 54-110.

46 Por. Sprawozdanie specjalne nr 15/2017. Warunki wstępne i rezerwa na wykonanie w obszarze spójności - instrumenty innowacyjne, lecz nieskuteczne, Europejski Trybunał Obrachunkowy, Luksemburg 2017 oraz M.W. Kozak, Reformy polityki spójności: czynniki, efekty, zagrożenia, [w:] Strategie gospodarcze i spoteczne Unii Europejskiej, red. J. Opolski, K. Górski, Warszawa 2015. 
Chociaż znaczenie podejścia inwestycyjnego w realizacji polityki regionalnej UE będzie rosnąć, przy jednoznacznej redukcji wydatków na rozwój infrastruktury technicznej i na projekty ponoszące standard życia mieszkańców regionów opóźnionych w rozwoju, nie należy zakładać całkowitej marginalizacji tych priorytetów. Wprawdzie, jak wskazują wyniki badań, rozwój infrastruktury technicznej nie ma bezpośredniego wpływu na generowanie wzrostu ekonomicznego ${ }^{47}$, jednak wyeliminowanie związanych z nim działań z finansowego wsparcia funduszy strukturalnych nie będzie możliwe, chociażby ze względu na polityczne priorytety państw, które finansują modernizację bazy infrastrukturalnej - z powodu jej deficytu, nadal obserwowanego w części uboższych regionów UE.

\section{BIBLIOGRAFIA}

Bachtler J., Begg I., Beyond Brexit: Reshaping policies for regional development in Europe, „Papers in Regional Science" 2018, vol. 97, nr 1, https://doi.org/10.1111/pirs.12351.

Bachtler J., Mendez C., Who Governs EU Cohesion Policy? Deconstructing the Reforms of the Structural Funds, „Journal of Common Market Studies” 2007, vol. 45, nr 3, https://doi. org/10.1111/j.1468-5965.2007.00724.x.

Banister D., Berechman Y., Transport investment and promotion of economic growth, „Journal of Transport Geography" 2001, vol. 9, nr 3, https://doi.org/10.1016/S0966-6923(01) 00013-8.

Bartoszewicz A., Instrumenty finansowe realizacji polityki spójności Unii Europejskiej, [w:] Perspektywy polityki gospodarczej, red. J. Stacewicz, Warszawa 2017, Prace i materiaty Instytutu Rozwoju Gospodarczego SGH, 99.

Begg I., The Future of Cohesion Policy in Richer Regions, „Working Papers. A Series of Short Papers on Regional Research and Indicators Produced by the Directorate-General for Regional Policy" 2009, nr 3, [online] http://ec.europa.eu/regional_policy/sources/docgener/ work/2009_03_richer.pdf.

Cappelen A., Castellacci F., Fagerberg J., Verspagen B., The Impact of EU Regional Support on Growth and Convergence in the European Union, "Journal of Common Market Studies" 2003, vol. 41, nr 4, https://doi.org/10.1111/1468-5965.00438.

D’Addato A., Williams A., Inspirujace praktyki w zakresie wczesnej interwencji i profilaktyki $w$ dziataniach na rzecz rodziny i wsparcia dla rodziców w Europie, „Dziecko krzywdzone. Teoria, badania, praktyka" 2013, vol. 12, nr 2 .

Dhéret C., Fransen L., 2017, Social Investment First! A Precondition for a Modern Social Europe, „European Policy Centre Issue Paper” 2017, nr 82, [online] http://aei.pitt.edu/85019/1/ pub_7468_socialinvestmentfirst.pdf.

Drożyński T., Efektywność polityki spójności UE i jej wptyw na rozwój regionów, [w:] Międzynarodowe stosunki gospodarcze - integracja regionalna w Europie i na świecie, red. T. Sporek,

47 D. Banister, Y. Berechman, Transport Investment and Promotion of Economic Growth, „Journal of Transport Geography” 2001, vol. 9, nr 3. 
Katowice 2012, Studia Ekonomiczne. Zeszyty Naukowe Wydziatowe Uniwersytetu Ekonomicznego w Katowicach, 123.

Europa 2020. Strategia na rzecz inteligentnego i zrównoważonego rozwoju sprzyjającego wtączeniu spotecznemu, Komisja Europejska, Bruksela 2010.

European Regional Competitiveness Index 2016, European Commission, [online] http://ec. europa.eu/regional_policy/en/information/maps/regional_competitiveness/.

GDP at Regional Level, Eurostat, [online] http://ec.europa.eu/eurostat/statistics-explained/index.php/GDP_at_regional_level.

Grosse T.G., Polityka spójności w dobie kryzysu strefy euro, „Studia Regionalne i Lokalne” 2016, nr 1(63), doi: 10.7366/1509499516301.

Inwestycje na rzecz wzrostu gospodarczego i zatrudnienia. Promowanie rozwoju i dobrego rzadzenia w regionach UE i miastach. Szósty raport na temat spójności gospodarczej, spotecznej i terytorialnej, Komisja Europejska, Bruksela 2014.

Klimowicz M., Ewolucja celów polityki regionalnej Unii Europejskiej w procesie integracji gospodarczej, [w:] Procesy integracyjne i dezintegracyjne w Europie. Podręcznik akademicki, red. A. Pacześniak, M. Klimowicz, Wrocław 2014.

Klimowicz M., Makarewicz-Marcinkiewicz A., Michalewska-Pawlak M., Moroń D., Inwestycje spoteczne jako innowacyjna metoda zarządzania zmiana spoteczna w kontekście regionalnym i krajowym w Polsce, Kraków 2018.

Kolczyński M., Żuber P., Nowy paradygmat rozwoju - najnowsze trendy i perspektywy polityki regionalnej, Warszawa 2011.

Kozak M.W., Polityka spójności 2014-2020: rewolucja, reforma czy utrzymanie status quo?, „Studia Regionalne i Lokalne” 2015, nr 4(62), https://doi.org/10.7366/1509499546201.

Kozak M.W., Reformy polityki spójności: czynniki, efekty, zagrożenia, [w:] Strategie gospodarcze i spoteczne Unii Europejskiej, red. J. Opolski, K. Górski, Warszawa 2015.

Makowska M., Polityka spójności po 2020 r. - ostrożna próba reformy, „Biuletyn PISM” 2018, nr 107(1680), [online] http://www.pism.pl/files/?id_plik=24702.

McCann P., Ortega-Argilés R., Redesigning and Reforming European Regional Policy: The Reasons, the Logic, and the Outcomes, "International Regional Science Review” 2012, nr 3(36), https://doi.org/10.1177/0160017612463234.

Michalewska-Pawlak M., Unia Europejska wobec paradygmatu inwestycji spotecznych, „Wrocławskie Studia Politologiczne” 2017, nr 23, https://doi.org/10.19195/1643-0328.23.7.

Michalewska-Pawlak M., Wielopoziomowy system zarządzania politykami regionalnymi państw cztonkowskich Unii Europejskiej jako rezultat procesów europeizacyjnych na przyktadzie Polski, [w:] Europeizacja polityk publicznych w Polsce, red. R. Riedel, Opole 2016.

Michalewska-Pawlak M., Wptyw wieloletnich ram finansowych 2021-2027 Unii Europejskiej na zarządzanie rozwojem regionalnym w Polsce, „Polityka i Społeczeństwo” 2019, nr 3(17), https://doi.org/10.15584/polispol.2019.3.4.

Michalewska-Pawlak M., Zarzadzanie rozwojem obszarów wiejskich $w$ Polsce w warunkach integracji europejskiej, Warszawa 2015.

Mój region, moja Europa, nasza przysztość. Siódmy raport na temat spójności gospodarczej, spotecznej i terytorialnej, Komisja Europejska, Bruksela 2017. 
Noworól A., Zarządzanie rozwojem w kontekście nowej polityki regionalnej, [w:] Zarządzanie publiczne: koncepcje, metody, techniki, red. A. Frączkiewicz-Wronka, Katowice 2013, Studia Ekonomiczne. Zeszyty Naukowe Wydziatowe Uniwersytetu Ekonomicznego w Katowicach, 169.

Pazderski F., Innowacyjne inwestycje spoteczne. W poszukiwaniu efektywnych odpowiedzi na wyzwania naszych czasów, Warszawa 2017, [online] http://www.isp.org.pl/uploads/pdf/ 622010832.pdf.

Pietrzyk I., Polityka regionalna Unii Europejskiej i regiony w państwach cztonkowskich, Warszawa 2000.

Population Statistics at Regional Level, Eurostat, [online] http://ec.europa.eu/eurostat/statis tics-explained/index.php/Population_statistics_at_regional_level\#Population_change.

Regional Innovation Scoreboard 2017, European Commission, [online] https://www.ewi-vlaanderen.be/sites/default/files/imce/ris2017_executive_summmary_en.pdf.

Rozporzadzenie Parlamentu Europejskiego i Rady (UE) nr 1301/2013 z dnia 17 grudnia 2013 r. w sprawie Europejskiego Funduszu Rozwoju Regionalnego i przepisów szczególnych dotyczacych celu „Inwestycje na rzecz wzrostu $i$ zatrudnienia” oraz w sprawie uchylenia rozporzadzenia (WE) nr 1080/2006, Dz.U. L 347 z 20.12.2013.

Rozporzadzenie Parlamentu Europejskiego i Rady (UE) nr 1303/2013 z dnia 17 grudnia 2013 r. ustanawiające wspólne przepisy dotyczące Europejskiego Funduszu Rozwoju Regionalnego, Europejskiego Funduszu Spotecznego, Funduszu Spójności, Europejskiego Funduszu Rolnego na rzecz Rozwoju Obszarów Wiejskich oraz Europejskiego Funduszu Morskiego i Rybackiego oraz ustanawiające przepisy ogólne dotyczące Europejskiego Funduszu Rozwoju Regionalnego, Europejskiego Funduszu Spotecznego, Funduszu Spójności i Europejskiego Funduszu Morskiego i Rybackiego oraz uchylające rozporzadzenie Rady (WE) nr1083/2006, Dz.U. L 347 z 20.12.2013.

Rozporzadzenie Parlamentu Europejskiego i Rady (UE) nr 1304/2013 z dnia 17 grudnia 2013 r. w sprawie Europejskiego Funduszu Spotecznego i uchylające rozporzadzenie Rady (WE) $n r$ 1081/2006, Dz.U. L 347 z 20.12.2013.

Sprawozdanie specjalne nr 15/2017. Warunki wstępne i rezerwa na wykonanie w obszarze spójności - instrumenty innowacyjne, lecz nieskuteczne, Europejski Trybunał Obrachunkowy, Luksemburg 2017.

Szlachta J., Terytorializacja jako wyzwanie polityki rozwoju-perspektywa europejska, „Studia KPZK” 2018, vol. 184.

Szlachta J., Zaleski J., Challenges of Future EU Cohesion Policy, „Gospodarka Narodowa” 2017, nr 5(291), https://doi.org/10.33119/GN/100731.

Szlachta J., Zaleski J., Strategiczne wybory polityki spójności UE po roku 2020 w świetle dokumentów programowych Komisji Europejskiej, „Studia KPZK” 2018, vol. 183.

Świstak M., Polityka regionalna Unii Europejskiej jako polityka publiczna. Wobec potrzeby optymalizacji publicznego dziatania, Kraków 2018.

Towards Social Investment for Growth and Cohesion - including implementing the European Social Fund 2014-2020, European Commission, 20 II 2013, [online] http://eurlex.europa. eu/LexUriServ/LexUriServ.do?uri=COM:2013:0083:FIN:en:PDF.

Unemployment Statistics, Eurostat, [online] http://ec.europa.eu/eurostat/statistics-explained/ index.php/Unemployment_statistics\#Youth_unemployment. 
Wiktorska-Święcka A., Klimowicz M., Michalewska-Pawlak M., Innowacje we wspótzarządzaniu rozwojem regionalnym. Praktyka instytucjonalna w wybranych polskich regionach, Wroclaw-Warszawa 2017.

Wiktorska-Święcka A., Klimowicz M., Michalewska-Pawlak M., Moroń D., Inwestycje spoteczne jako nowy paradygmat polityk publicznych w Unii Europejskiej, Warszawa 2017.

Małgorzata MICHALEWSKA-PAWLAK - doktor habilitowana w zakresie nauk o polityce, adiunkt w Zakładzie Europejskiej Integracji Gospodarczo-Społecznej i Rozwoju Regionalnego Katedry Studiów Europejskich Uniwersytetu Wrocławskiego. Obszary badawcze: terytorialne polityki Unii Europejskiej, zarządzanie rozwojem lokalnym i regionalnym, inwestycyjna polityka społeczna.

Monika KLIMOWICZ - doktor habilitowana w zakresie nauk o polityce, ekonomista, adiunkt w Zakładzie Europejskiej Integracji Gospodarczo-Społecznej i Rozwoju Regionalnego Katedry Studiów Europejskich Uniwersytetu Wrocławskiego. Obszary badawcze: społeczno-gospodarcze aspekty integracji europejskiej, inwestycje społeczne, innowacje w zarządzaniu publicznym. 